\title{
Toxicity of orally administered food-grade titanium dioxide nanoparticles
}

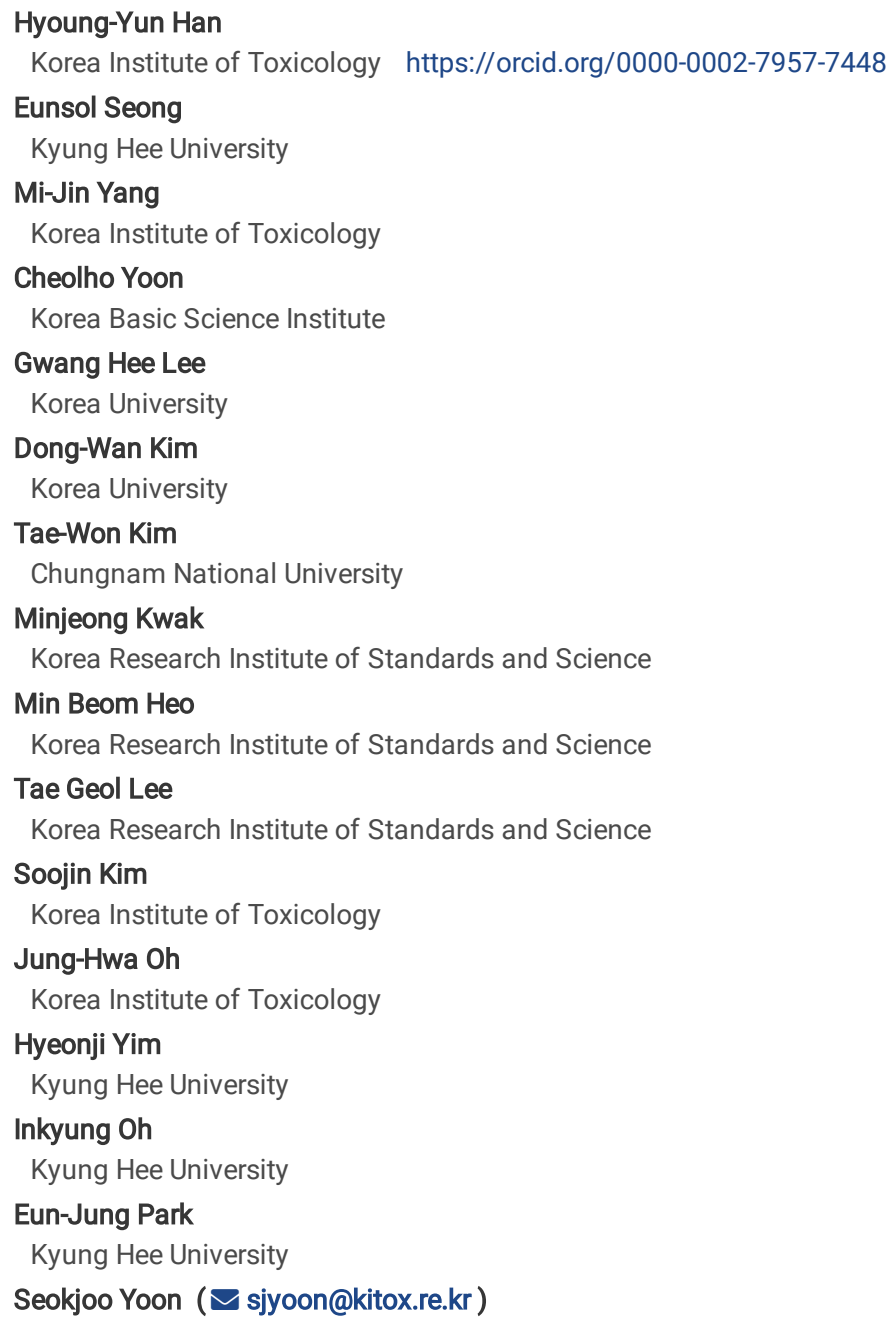

Keywords: TiO2 E171, Nanoparticles, Subchronic toxicity, Oral toxicity, NOAEL

Posted Date: June 9th, 2020

DOI: https://doi.org/10.21203/rs.3.rs-33962/v1

License: @ (i) This work is licensed under a Creative Commons Attribution 4.0 International License. Read Full License

Version of Record: A version of this preprint was published at Journal of Applied Toxicology on November 25th, 2020. See the published version at https://doi.org/10.1002/jat.4099. 


\section{Abstract}

Background The International Agency for Research on Cancer classified as a Group B carcinogen inhaled titanium dioxide (TiO 2 ) nanoparticles, and France banned the application of TiO 2 nanoparticles as a food additive based on the insufficient oral toxicity data. However, there still remains controversial due to the insufficient evidence for its safety. Here, we explored the toxicity of food-grade TiO 2 nanoparticles (hereafter, E171) in vivo and in vitro . Methods We investigated the subchronic toxic responses of E171 $(0,10,100$, and $1,000 \mathrm{mg} / \mathrm{kg}$ ) under the Good Laboratory Practice (GLP) system and tried to elucidate the possible toxic mechanism using AGS cells, a human stomach epithelial cell line. Results There were no dose-related changes in the Organization for Economic Co-operation and Development test guideline-related endpoints. Meanwhile, E171 deeply penetrated cells lining the stomach tissues of rats administered the maximum dose, and blood IgM (male and female) and GM-CSF (female) levels were significantly lower in the E171-treated rats than in the control rats. Colonic SOD-1 (male and female) and SOD-2 (female) protein levels decreased with increasing Ti accumulation. When exposed to AGS cells for 24 h, E171 (40 $\mu \mathrm{g} / \mathrm{mL}$ ) located in the perinuclear region. The E171 treatment affected expression of ER stress-related proteins but did not induce cell death up to the used maximum concentration $(40 \mu \mathrm{g} / \mathrm{mL})$. A gene profile analysis also showed that immune response-related microRNAs were most strongly affected by E171 exposure. Conclusion Considering the potential toxicity observed in vivo and in vitro test, we concluded that the NOAEL of E171 for 90 -days repeated oral administrations is less than $1,000 \mathrm{mg} / \mathrm{kg}$ for both male and female rats. Additionally, E171 may attenuate host's defense function against foreign bodies by decreasing antioxidant capacity, thus we propose that chronic toxicity studies on E171 are required to warrant the safety for use in the food industry.

\section{Background}

Owing to the beneficial properties which are bright white, poorly water soluble and inactive, titanium dioxide $\left(\mathrm{TiO}_{2}\right)$ particles have been used to manufacture a wide range of products including cosmetics, skin care products, paints, and building materials as a pigment (called as Pigment White 6 or Cl77891) for about 100 years [12,39]. Market survey data also suggested that paints, varnishes, paper, and plastics account for $\sim 80 \%$ of the global $\mathrm{TiO}_{2}$ consumption $[8]$. In addition, in 1969, the Joint FAO/WHO Expert Committee of Food Additives (JECFA) evaluated $\mathrm{TiO}_{2}$ as a food additive and designated an acceptable daily TiO 2 intake as 'not limited except for good manufacturing practice'. The Scientific Committee on Food (SCF) classified TiO ${ }_{2}$ as 'colours for which an acceptable daily intake (ADI) was not established but which could be used in food' in 1977 [2]. Similarly, the U.S. Food and Drug Administration (FDA) accepted the addition of $\leq 1 \%$ food grade- $\mathrm{TiO}_{2}$ (called as $\mathrm{E} 171 \mathrm{in} \mathrm{EU}$ ) to food products without the requirement of ingredient label disclosure [36].Thus, $\mathrm{TiO}{ }_{2}$ particles have been extensively used in the production of various foodstuffs such as chocolates, candies, chewing gum, ice cream, donuts, confectionery, and beverages, they have been also incorporated into toothpaste and pharmaceutical products [11].

Meanwhile, the application of $\mathrm{TiO}_{2}$ particles in the food industry has been a major public concern for a long period of time regarding the direct exposure, especially in children who tend to like eating sweets, and this concern has been amplified with the growth of the nanoindustry. In addition, the International Agency for Research on Cancer (IARC) classified inhaled $\mathrm{TiO}_{2}$ nanoparticles as a Group 2B (potential human carcinogen), particularly for workers [16]. France, which worked as a lead sponsor in a sponsorship program of the Organisation for Economic Cooperation and Development (OECD) working party for manufactured nanomaterials, also reviewed the health effects of food-grade $\mathrm{TiO}_{2}$ nanoparticles (hereafter, E171) in 2017 [3], and France's National Institute for Agricultural Research (INRA) and its colleagues reported that oral dosed-E171 may cross the intestinal wall and be translocated to other organs and tissues via the bloodstream [5]. They demonstrated that the adverse health effects of E171 exposure are attributable to the absorption of the nanoscale but not the microscale particle fraction and that E171 disturbs the homeostasis of the immune system. Similarly, about $36 \%$ of the particles obtained from a single source

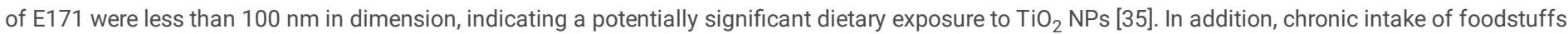
containing E171 initiated and promoted the expansion of preneoplastic lesions in the colon and induced a slight inflammatory microenvironment in the mucosa [10]. Therefore, France banned the use of $\mathrm{TiO}_{2}$ as a food additive in 2020 based on inadequate evidence to guarantee its safety to humans. In this study, our objective was to explore the possible adverse health effects of E171 orally administered to rats for 90 days. We also investigated the potential toxic mode of action of E171 in AGS cells, a human stomach epithelial cell line.

\section{Results}

\section{Characterization of $\mathrm{TiO}_{2} \mathrm{NPs}$}

Figure 1 shows typical transmission electron microscope (TEM) images of E171. The mean particle diameter was about $150 \mathrm{~nm}$ and there was a single anatase phase (PDF card No. 21-1272) in distilled water (DW). The diameter and shape were not notably altered either in artificial gastric fluid (AGF) [23] or cell culture media. High-resolution (HR)-TEM images also revealed highly crystalline structures with a 0.35-mm lattice spacing corresponding to the (101) plane of the anatase phase (Figure 1A). In DW, AGF, and cell culture media, its average hydrodynamic diameters were $301.1 \mathrm{~nm}, 1,954.7 \mathrm{~nm}$, and $627.4 \mathrm{~nm}$, respectively (Figure 2B) and its surface charge values were $-44.16 \mathrm{mV}, 4.89 \mathrm{mV}$, and -25.78 mV, respectively (Figure 2C).

\section{General observations}

All animals were alive until dosing was terminated. Abnormal clinical signs such as fur loss, scabs, scars, scratch wounds, swelling, and discolored urine were observed in the E171-dosed rats, but these effects were not considered to be dose-dependent. While body weight did not significantly differ among groups (Table S1), a significant increase in food consumption was observed in male rats dosed at 1,000 mg/kg (Table 1).

\section{Clinical analysis}

As shown in Table 2, the proportion of lymphocytes in WBC slightly decreased in male rats administered the maximum E171 dose. There were no dose-related changes in any hematological (Table2) or biochemical (Table 3) parameters, absolute organ weight (Table 4), or organ weight relative to body weight (Table 


\section{E171 accumulation in the stomach wall}

There are no remarkable changes in macroscopic finding (data not shown), dose-related histopathological lesions were also not detected. Meanwhile, we found E171 accumulation in the stomach wall of several rats administered 1,000 mg/kg E171 for 90 days (Figure 2).

\section{The main routes of excretion}

$\mathrm{TiO}_{2}$ has low water solubility but can be dissolved in the acidic conditions such as gastric juice and lysozyme. Additionally, the damaged macrophages are eliminated via the spleen. In the current study, we measured Ti concentrations in the colons, kidneys, and spleens harvested from all rats at necropsy. Importantly, the Ti concentration clearly increased only in the colons of both sexes administered 1,000 mg/kg E171 compared with the control, indicating that the colon is the main excretion route (Table 7). In addition, TEM images revealed that E171 accumulates in the cytosol and nuclei of various cells comprising the colon tissue and forms lamella-like structures in the colon tissues (Figure 3). Ti accumulation can also affect the distribution of elements cross-binding with it or participating in the antioxidant response, and we here found that the colonic Zn concentration increases in female rats exposed to E171 compared with the control. In addition, superoxide dismutases (SOD) play a central role in inhibiting xenobiotic-induced oxidative damage and subsequent apoptosis [15], thus we assessed the effects of E171 on expression of SOD-1, SOD-2, and cytochrome $C$ protein in the colonic tissues of rats in control and the maximum dose group. Interestingly the expression of SOD-1 and SOD-2 protein were clearly down-regulated in the colonic tissues of both sexes and female rats, respectively. However, cytochrome $\mathrm{C}$ expression did not significantly differ among treatment groups (Figure 4).

\section{Effects of E171 on systemic immune response}

Given that the proportion of lymphocytes in WBC decreased in rats administered with the maximum dose compared to control, we measured the GM-CSF and immunoglobulin concentrations in the blood. Importantly, the levels of GM-CSF (female) and IgM (both sexes) significantly reduced in rats administered with $1,000 \mathrm{mg} / \mathrm{kg}$ E171 for 90 days compared with the control (Figure 5), whereas there were no differences among treatment groups in terms of their IgG, IgA, or IgE levels. The GM-CSF levels were $46.3 \pm 12.1 \mathrm{pg} / \mathrm{mL}$ and $27.3 \pm 9.3 \mathrm{pg} / \mathrm{mL}$ for the female rats in the control and maximum-dose groups, respectively. The IgM levels were $2,123.6 \pm 176.3 \mathrm{ng} / \mathrm{mL}$ and $1,926.6 \pm 77.3 \mathrm{ng} / \mathrm{mL}$ in the male and female rats of the control group, respectively, whereas they were $1,886.9 \pm$ $87.7 \mathrm{ng} / \mathrm{mL}$ and $1,696.5 \pm 152.7 \mathrm{ng} / \mathrm{mL}$ for the male and female rats in the maximum-dose group, respectively.

\section{Cellular response following accumulation of E171}

E171 accumulated in cells lining the stomach wall of rats administered 1,000 mg/kg E171 for 90 days, thus we investigated the possible toxic mechanism following accumulation of E171 using AGS cells, a human stomach epithelial cell line. We first confirmed that E171 localize to the perinuclear region of the AGS cells on $24 \mathrm{~h}$ after treatment $(40 \mu \mathrm{g} / \mathrm{mL}$ ) (Figure 6). The expression of the endoplasmic reticulum (ER) stress (calnexin, IRE-1a, Bip, PERK and Ero-1a)-, pyroptosis (caspase-1, IL-18, and NALP3)-, autophagy (p62 and LAMP-1)-, and ferroptosis (ferritin heavy chain) [26] -related proteins was enhanced in the E171-treated cells compared to control accompanied by the peroxisomal (catalase) and mitochondrial antioxidant (SOD-2) [30, 38]. Meanwhile, there were no significant changes in both the level of CHOP and phosphor-JNK (which play in ER stress-triggered apoptosis [24, 25]), and the cytosolic antioxidant protein (SOD-1) and conversion of LC3B-I into LC3B-II (completion of autophagosome) (Figure 7). In addition, the expression levels of various microRNAs and unknown genes were markedly altered in the E171-exposed cells relative to the control (Table 8). More interestingly, cell death were not observed even at the highest concentration tested $(40 \mu \mathrm{g} / \mathrm{mL})$.

\section{Discussion}

The potential risks of nanoscale particles on the environment and human health have been continuously issued along with the great importance in future industry, thus nanotechnology has often been compared to a double-edged sword [18, 28, 34]. Meanwhile, all substance is potentially harmful to human health when it accumulates at sufficiently high concentrations to disturb biological homeostasis. Indeed, the Swiss physician Paracelsus stated that the dose makes the poison. Furthermore, nanoscale particles have unique physicochemical properties that differ from those of the bulk forms of the same materials. Therefore, although available information for the microscale particles is enough, biostability, interactions with biological systems, biodistributions, health effects and the possible toxic mechanism should be carefully reevaluated for the nanoscale particles [13]. Here, we found that E171 is insoluble in DW, a vehicle used for dosing, and the physicochemical properties were not substantially altered in AGF or cell culture media. In addition, when orally dosed 10,100 and $1000 \mathrm{mg} / \mathrm{kg}$ to rats for 90 days in accordance with an OECD test guideline [27], any significant tissue damage was not found even in the maximum dose. Meanwhile, contrary to the Titanium Dioxide Manufacturers' Association' claim that it is not readily absorbed by the human body, E171 markedly penetrated and accumulated in the stomach walls of rats administered $1,000 \mathrm{mg} / \mathrm{kg}$. Moreover, E171 penetrated the plasma membranes of AGS cells derived from stomach epithelial tissue, E171 also formed lamella-like structures [9] and autophagosome-like vacuoles in the colon and the AGS cells, respectively. Lysosomes serve for both degradation of materials taken up from outside the cells and digestion of the cell's own components with enzymes which are active at the acidic conditions. In addition, lamella bodies and autophagosomes are associated with early defense mechanisms against foreign bodies and are characteristic of various lysosomal storage diseases. Therefore, we propose that the NOAEL of E171 for 90 -days repeated oral dosing is less than 1000 $\mathrm{mg} / \mathrm{kg}$.

According to epidemiological evidence, the incidences of colorectal and gastric cancer are globally increasing. Moreover, as mentioned above, inhaled $\mathrm{TiO}_{2}$ NPs were classified as a Group B2 carcinogen by IARC, and France has banned the use of E171 as a food additive until the safety has been empirically and clinically verified. Although ingested nanoparticles are excreted mainly via the feces, they can be resorbed from the kidney depending on their biostability, and NPs that have entered the bloodstream can be removed by the spleen. A previous study suggested that E171 administered orally for 90 days at 10 mg/kg 
induced an inflammatory response and caused poor liver function via oxidative stress. A 100-day repeated dosed-E171 also promoted micro-inflammation and initiated preneoplastic lesions in the colons, and it altered the expression of genes involved in innate and adaptive immune and oxidative stress responses [7]. In the current study, Ti concentrations notably increased in the colonic tissues and altered the antioxidant SOD expression levels there. Hence, we guess that part of E171 may be dissolved under the acidic conditions of the stomach and that the rest may form aggregates with diet or other particles. As well, it may affect antioxidant capacity being resorbed during the stay in the colon [20,29, 31]. We also found that the proportion of lymphocytes in WBC was clearly lower in rats exposed to E171 compared with the control and that the GM-CSF and IgM levels notably reduced in the blood of rats in the same group. GM-CSF regulates myelopoiesis in physiological steady state and modulates immunity under inflammatory conditions including autoimmune disease [4, 6]. In addition, IgM is the antibody that is produced mainly in the spleen in response to initial antigen exposures. Therefore, we hypothesize that chronic E171 intake might impair host's defense function against foreign bodies.

The reassessment of E171 as a putative carcinogen may be crucial in the determination and establishment of its safety [1, 14, 17, 37]. Accumulated clinical and empirical evidence has demonstrated that $\mathrm{TiO}_{2}$ nanoparticles induce ER stress by promoting oxidative stress. In addition, chronic ER stress may be associated with tumor development by triggering an inflammatory response [21], it could also be involved in immunosuppression [32]. In this study, we found that E171 did not affect expression of SOD-1 and SOD-2 protein in AGS cells. In addition, E171 penetrated the cells comprising the colon tissue and localized to the perinuclear regions of AGS cells. Meanwhile, dead cells was not observed even in cells treated at the maximum concentration ( $40 \mathrm{\mu g} / \mathrm{mL})$. Furthermore, the expression of ER stress-related proteins increased in E171-treated cells compared to control, and microarray analysis demonstrated that that expression of several microRNAs the most affected following exposure to E171. In particularly, the expression of microRNA3908 was the most down-regulated. More interestingly, many of the affected genes were genes whose the function is unknown. microRNAs are non-coding RNAs that are involved in post-transcriptional regulation by affecting both the stability and translation of mRNA. Previous studies have suggested that microRNA 3908 inhibits cancer progression by inducing apoptosis [22] and that bitter-taste receptor genes (such as TAS2R50) can be involved in progression of colorectal neoplasia [33]. In addition, SOD-2 transforms toxic mitochondrial superoxide into non-toxic products, inhibiting apoptosis, ferritin heavy chain also protect cells against free radical accumulation [26]. Furthermore, ER stress can initiate pyroptosis and inflammasome formation [19]. Therefore, further study is required to elucidate the adverse health effects following chronic accumulation in the stomach and colons [31].

In conclusion, we suggest that NOAEL of 90 -day repeated oral dosed-E171 is less than $1,000 \mathrm{mg} / \mathrm{kg}$ for both sexes of rats and that further study is needed to clarify pathology following the chronic accumulation in the colons.

\section{Methods}

\section{Characterization}

E171 (HOMBITAN ${ }^{\circledR}$ FG; Purity 99.5\%) was purchased from Venator Germany GmbH (Duisburg, Germany) and suspended in DW (stock concentration of 100 $\mathrm{mg} / \mathrm{mL}$ ). The suspension was added to AGF and cell culture medium to evaluate its stability in biological systems. Particle morphology was observed by TEM (JEM-3000F, 200 kV, JEOL Ltd., Tokyo, Japan), and particle size distribution and surface charge were measured with a zeta-potential and particle size analyzer (ELSZ-1000 Photal; Otsuka Electronics, Osaka, Japan).

\section{Animals and housing}

Five-week-old male and female specific pathogen-free SD rats (fifty rats per sex) were obtained from Orient Bio Inc. (Seongnam-si, Gyeongi-do, Korea) and maintained in a controlled environment (stainless wire cages $255 \mathrm{~mm} \mathrm{~W} \times 465 \mathrm{~mm} \mathrm{~L} \times 200 \mathrm{~mm} \mathrm{H}$ (five rats/cage), $12 \mathrm{~h} / 12 \mathrm{~h}$ light/dark cycle, temperature 23 $\pm 3{ }^{\circ} \mathrm{C}$, relative humidity $50 \pm 10 \%$, air ventilation 10-20x/h, light intensity $150-300 \mathrm{~lx}$, and ad libitum access to food (PMI Nutrition International, St. Louis, MO, USA) and tap water. The rats were randomly assigned to one of four groups $(0,10,100$, or 1,000 mg/kg) via Pristima v. 7.4 (Xybion Medical Systems Corporation, Lawrenceville, NJ, USA). E171 (10 rats/sex/dose) was administered daily by oral gavage for 13 consecutive weeks. The control group received equal volumes of DW. The experimental design was reviewed and assessed by the Association for the Assessment and Accreditation of Laboratory Animal Care International (AAALAC) and the Institutional Animal Care and Use Committee (IACUC) of the Korea Institute of Toxicology.

\section{Clinical observations and assessments}

The health status of all rats was observed daily according to a predetermined schedule during the study period. The type, time of occurrence, and severity of abnormal symptoms were recorded with the Pristima v. 7.4 system. The rats were weighed upon arrival, before randomization, weekly during pretreatment, before dosing during treatment, and before necropsy. Food consumption was recorded once weekly during the pretreatment and treatment periods and calculated as $\mathrm{g} / \mathrm{rat} /$ day. Urinalysis was performed during the treatment period on all surviving animals being administered E171. The urine was collected for $\sim 17 \mathrm{~h}$ before necropsy and its volume, specific gravity (SG), color, $\mathrm{pH}$, and protein (PRO), ketone body (KET), occult blood (BLD), glucose (GLU), bilirubin (BIL), nitrite (NIT), and urobilinogen (URO) levels were measured with a Cobas U411 urine analyzer (Roche, Basel, Switzerland) and a urine chemical analyzer (TBA 120FR; Toshiba Corp., Tokyo, Japan). The urine was centrifuged (1500 rpm, $5 \mathrm{~min}$ ) and its sediment casts (epithelial cells (EPI), erythrocytes (RBC), leucocytes (WBC), and blood (BLO) were stained and microscopically observed (Nikon Eclipse Ci, Nikon, Japan). Upon necropsy, blood was drawn from the venae cavae of all rats and stored in tubes coated with EDTA-2K and heparin. Hematological and clinical chemistry analyses were performed in an ADVIA 2102i hematology system (Siemens, Washington, DC, USA) and an automatic analyzer (TBA 120FR; Toshiba Corp., Tokyo, Japan), respectively.

\section{Macroscopic and microscopic findings}

At necropsy, 42 tissue samples were taken from all rats. The eyes with optic nerves intact were weighed and fixed in Davidson's fixative solution. All other tissues were weighed and preserved in $10 \%(\mathrm{v} / \mathrm{v})$ neutral buffered formalin. All preserved tissues were embedded in paraffin, sectioned, stained with 
hematoxylin and eosin (H\&E), and examined under microscope (Olympus BX53, Olympus America, USA). Relative organ weights were calculated using the body weights measured at necropsy.

\section{TEM images}

The colons obtained from rats administered the maximum dose were chopped, and AGS cells were incubated with $40 \mu \mathrm{g} / \mathrm{mL}$ E171 for $24 \mathrm{~h}$. The stomach tissues and the AGS cells were put in Karnovesky's fixative solution (Electron Microscopy Sciences, Hatfield, PA, USA) overnight at $4{ }^{\circ} \mathrm{C}$. The cells were then fixed in a mixture of $2 \%(\mathrm{v} / \mathrm{v})$ glutaraldehyde and $0.1 \mathrm{M}$ sodium cacodylate buffer for $2 \mathrm{~h}$, stained with $0.5 \%$ ( $/ \mathrm{v}$ ) uranyl acetate, dehydrated in graded ethanol solutions and propylene oxide, and embedded in Spurr's resin (Electron Microscopy Sciences, Hatfield, PA, USA). The colon tissues and AGS cells were sectioned with an ultramicrotome (MT-X; RMC, Tucson, AZ, USA), stained with $2 \%$ (w/v) uranyl acetate and Reynolds's lead citrate, and imaged with a transmission electron microscope (TEM) at 120 kV (Talos L120C, FEl, Hillsboro, OR, USA) as well as an 80-kV TEM (JEM1010, JEOL, Tokyo, Japan).

\section{Immunohistochemistry}

Paraffin-embedded stomach tissues were dewaxed with xylene and a graded alcohol series (100\%, 95\%, $70 \%$, and $50 \%)$. After washing with phosphatebuffered saline (PBS), the tissues were placed in an antigen retrieval solution (ENZO; Seoul, Korea) and permeabilized with PBS containing Tween-20 (PBST, $1 \%)$. After blocking with $5 \%(\mathrm{v} / \mathrm{v})$ bovine serum albumin (BSA) in PBST $(0.01 \%)$, the tissues were incubated overnight with rabbit polyclonal antibody against superoxide dismutase (SOD)-1 and SOD-2 (Santa Cruz Biotechnology; Dallas, TX, USA) and cytochrome C (Cell Signaling Technology, Danvers, MA, USA) at 4 ${ }^{\circ} \mathrm{C}$. Following, the tissues were reacted with affinity-purified Alexa Fluor 488-conjugated goat anti-rabbit IgG (Invitrogen, Carlsbad, CA, USA) and mounted with 4',6-diamidino-2-phenylindole (DAPI) mounting medium. Lastly, the images were then captured with an inverted phase-contrast fluorescence microscope (IX51, Olympus, Tokyo, Japan).

\section{Trace element determination by ICP-MS}

The tissues (colons, spleens, and kidneys) were digested in $70 \%(\mathrm{v} / \mathrm{v})$ nitric acid solution using a microwave digestion system (Milestone; Sorisole, Italy). Finally, concentrations of trace elements (Al, Cu, Zn, Mn and Fe) in tissues were measured by inductively coupled plasma mass spectrometry (ICP-MS) at the Korean Basic Science Institute (Seoul, Korea).

\section{Western blotting}

AGS cells (70 - $80 \%$ of confluence) were incubated with $\mathrm{E} 171(0,10,20,40 \mu \mathrm{g} / \mathrm{mL})$ for $24 \mathrm{~h}$. As described previously, proteins in the cell lysates were quantified by bicinchoninic acid assay (Sigma-Aldrich, St. Louis, MO, USA), and the same amounts of proteins were electrophoretically separated on SDS polyacrylamide gel. Then, the proteins were transferred to nitrocellulose membranes $(0.45 \mu \mathrm{m}$ pore, GE Healthcare Life Sciences, Freiburg, Baden-Württemberg, Germany) and blocked with $5 \%(\mathrm{v} / \mathrm{v})$ skim milk in PBST (0.05\%). The membranes were reacted overnight at $4{ }^{\circ} \mathrm{C}$ with primary mouse monoclonal antibodies against lysosome-associated membrane protein (LAMP)-1, $\beta$-actin, ER oxidoreductin (ERO)-1alpha, ferritin (HC), phospho-JNK, protein disulfide isomerase (PDI), eukaryotic translation initiation factor (elF)2-alpha, catalase, caspase-1 (Santa Cruz Biotechnology, Dallas, TX, USA), C/EBP homologous protein (CHOP) (Cell Signaling Technology, Danvers, MA, USA), p62 (Abcam, Cambridge, UK), and rabbit monoclonal antibody against protein kinase RNA-like endoplasmic reticulum kinase (PERK), inositol-requiring enzyme (IRE)1-alpha (Cell Signaling Technology, Danvers, MA, USA), and rabbit polyclonal antibody against superoxide dismutase (SOD)-1, SOD-2, interleukin (IL)-18 (Santa Cruz Biotechnology, Dallas, TX, USA), binding immunoglobulin protein (Bip), calnexin, microtubule-associated proteins 1A/1B light chain (LC)3B (Cell Signaling Technology, Danvers, MA, USA), and goat polyclonal antibody against NACHT, LRR and PYD domains-containing protein (NALP)3 (Abcam, Cambridge, UK). The proteins were then reacted with HRP-conjugated mouse and rabbit or goat secondary antibodies (Santa Cruz Biotechnology, Dallas, TX, USA) and blotted in a ChemiDoc XRS+ system (Bio-Rad Laboratories, Hercules, CA, USA).

\section{Gene profiling analysis}

AGS cells were incubated with or without E171 $(40 \mu \mathrm{g} / \mathrm{mL})$ for $24 \mathrm{~h}$. The effects of E171 on the gene profile were evaluated by microarray analysis. Briefly, the mRNA was prepared and the microarray analysis was conducted at Macrogen (Seoul, Korea) using an Affymetrix ${ }^{\circledR}$ uman $2.0 S T$ gene chip according to the manufacturer's instructions (Illumina, San Diego, CA, USA). The data were summarized and normalized by the robust multi-average (RMA) method in Affymetrix ${ }^{\circledR}$ Power Tools (APT). The results of the gene-level RMA analysis were exported and a differentially expressed gene (DEG) analysis was performed. Statistical significance of the expression data was determined by fold change. For each DEG set, a hierarchical cluster analysis was conducted using complete linkage and Euclidean distance as measures of similarity. Gene enrichment and functional annotation analyses of significant probe lists were performed via GO (http://geneontology.org) and KEGG (www.genome.jp/kegg/). All data analyses and DEG visualizations were performed in R v. 3.3.3 (www.rproject.org).

\section{Statistical analysis}

Data were statistically analyzed by multiple comparison methods. When Bartlett's test revealed no significant deviations from variance homogeneity, ANOVA was used to determine whether any group means differed at the $P<0.05$ level. Dunnett's test was used to identify differences in the means for the control and treatment groups when the data were found to be significant according to ANOVA. When significant deviations from variance homogeneity were identified by Bartlett's test, the nonparametric Kruskal-Wallis $(\mathrm{H})$ test was conducted to establish whether any of the group means differed at the $P<0.05$ level. When significant differences were observed by the Kruskal-Wallis $(\mathrm{H})$ test, Dunn's Rank Sum test was conducted to identify the pairs of group data that significantly differed from the mean. Fisher's exact test was run to compare data pairs including prevalence and percentage. The probability level was $1 \%$ or $5 \%$. Statistical analyses were performed using Prisitima v. 7.4 by comparing the data of the various treatment groups with those of the control. 


\section{Abbreviations}

ADI, acceptable daily intake; AGF, artificial gastric fluid; Apaf-1, apoptotic-protease activating factor; APT, Affymetrix ${ }^{\circledR}$ Power Tools; BCA, bicinchoninic acid; BSA, bovine serum albumin; DAPI, 4',6-diamidino-2-phenylindole; DEG, differentially expressed gene; EGFR, epidermal-growth-factor receptor; ER, endoplasmic reticulum; FAO, Food and Agriculture Organization; GLP, Good Laboratory Practice; GLU, glucose; GM-CSF, granulocyte-macrophage colony-stimulating factor; GMP, Good Manufacturing Practice; GO, gene ontology; ICP-MS, inductively coupled plasma mass spectrometry; INRA, National Institute for Agricultural Research; JECFA, Joint FAO/WHO Expert Committee of Food Additives; KEGG, Kyoto Encyclopedia of Genes and Genomes; LAMP-2, lysosome-associated membrane protein; MFN1, mitofusin; NIT, nitrite; NOAEL, no observable adverse effects level; PARP, poly(ADP-ribose) polymerase; PBST, phosphate-buffered saline containing 1\% (w/v) Tween-20; RMA, robust multi-average; SCF, Scientific Committee on Food; SG, specific gravity; SOD, superoxide dismutase; TEM, transmission electron microscopy; $\mathrm{TiO}_{2}$, titanium dioxide; V-ATPase, vacuolar-type $\mathrm{H}^{+}$-ATPase

\section{Declarations}

\section{Acknowledgements}

The authors would like to gratefully acknowledge the support of the EU Horizon 2020-PATROLS project (grant agreement No. 760813).

\section{Authors' contributions}

Hyoung-Yun Han designed the experiments, prepared the treatments, and wrote the draft. Mi-Jin Yang performed the histopathological analyses. Gwang Hee Lee and Dong Wan Kim characterized the NPs and wrote the draft. Tae-Won Kim performed the validations and the formal analyses. Soojin Kim, Minjeong Kwak and Beom Heo organized the data. Tae Geol Lee manufactured the NPs. Jung-Hwa Oh designed the experiment and prepared the treatments. Eun-Jung Park designed the experiments, performed in vitro test, wrote the original draft and author responses, edited the manuscript, and secured the funding. Cheolho Yoon; done ICP/MS analysis. Eunsol Seong, Hyun-Ji Lim and Inkyung Oh; performed tissue lysis, IHC, and in vitro test. Seokjoo Yoon revised the manuscript and acquired the funding and resources.

\section{Funding}

This work was supported by a grant from Ministry of Science and ICT (NRF-2015M3A7B6027948 and NRF-2016M3A9C4953144), fund of Kyung Hee University (20180872 and 20192100), and the Korea Institute of Toxicology (KK-2001).

\section{Availability of data and materials}

The datasets used and/or analyzed during the current study are available from the corresponding author on reasonable request.

\section{Ethics approval}

All animal protocols were prepared in accordance with the Animal Protection Act of Korea and Guide for the Care and Use of Laboratory Animal published by the Institute for Laboratory Animal Research (ILAR). This animal study was approved by the Institutional Animal Care and Use Committee (IACUC) of KIT.

\section{Consent of publication}

Not applicable.

\section{Competing interests}

All authors declare that they have no competing interests.

\section{References}

1. Armand L, Tarantini A, Beal D, Biola-Clier M, Bobyk L, Sorieul S, Pernet-Gallay K, Marie-Desvergne C, Lynch I, Herlin-Boime N, Carriere M. Long-term exposure of A549 cells to titanium dioxide nanoparticles induces DNA damage and sensitizes cells towards genotoxic agents. Nanotoxicology. 2016;10(7):913-23.

2. ANS, EFSA. Re-evaluation of titanium dioxide (E 171) as a food additive. EFSA Journal. 2016;14(9):e04545.

3. Titanium dioxide nanoparticles in food (additive E171): biological effects need to be confirmed. https://www.anses.fr/en/content/titanium-dioxidenanoparticles-food-additive-e171-biological-effects-need-be-confirmed. Accessed at 31 May 2020.

4. Becher B, Tugues S, Greter M. GM-CSF: From Growth Factor to Central Mediator of Tissue Inflammation. Immunity. 2016;45(5):963-73.

5. Bettini S, Boutet-Robinet E, Cartier C, Coméra C, Gaultier E, Dupuy J, Naud N, Taché S, Grysan P, Réguer S, Thieriet N, Réfrégiers M, Thiaudière D, Cravedi JP, Carriere M, Audinot JN, Pierre F, Laurence gp, Houdeau E. Food-grade TiO2 impairs intestinal and systemic immune homeostasis, initiates preneoplastic lesions and promotes aberrant crypt development in the rat colon. Sci Rep. 2017;20(7):40373.

6. Bhattacharya P, Thiruppathi M, Elshabrawy HA, Alharshawi K, Kumar P, Prabhakar BS. GM-CSF: An immune modulatory cytokine that can suppress autoimmunity. Cytokine. 2015; 75(2):261-71.

7. Blevins LK, Crawford RB, Bach A, Rizzo MD, Zhou J, Henriquez JE, Khan DMIO, Sermet S, Arnold LL, Pennington KL, Souza NP, Cohen SM, Kaminski NE. Evaluation of immunologic and intestinal effects in rats administered an E 171-containing diet, a food grade titanium dioxide (TiO2). Food Chem Toxicol. 
2019;133:110793.

8. Brandessence Market Research and Consulting PVT. LTD. Titanium Dioxide Market 2019 Industry Size, Share, Trends, Growth, Opportunities, Competitive Analysis and Forecast to 2025. https://www.medgadget.com/2020/04/titanium-dioxide-market-2019-industry-size-share-trends-growth-opportunitiescompetitive-analysis-and-forecast-to-2025.html. Accessed at 31 May 2020.

9. Cheong N, Zhang H, Madesh M, Zhao M, Yu K, Dodia C, Fisher AB, Savani RC, Shuman H. ABCA3 is critical for lamellar body biogenesis in vivo. J Biol Chem. 2007;282:23811-17.

10. Dorier M, Tisseyre C, Dussert F, Béal D, Arnal ME, Douki T, Valdiglesias V, Laffon B, Fraga S, Brandão F, Herlin-Boime N, Barreau F, Rabilloud T, Carriere M. Toxicological impact of acute exposure to E171 food additive and TiO2 nanoparticles on a co-culture of Caco-2 and HT29-MTX intestinal cells. Mutat Res. 2019;845:402980.

11. Dudefoi W, Moniz K, Allen-Vercoe E, Ropers MH, Walker VK. Impact of food grade and nano-TiO2 particles on a human intestinal community. Food Chem Toxicol. 2017;106(Pt A):242-49.

12. European Union. European Parliament and Council Directive 94/36/EC of 30 June 1994 on colours for use in foodstuffs. In: Official Journal of the European Communities. European Communities. 1994. https://eur-lex.europa.eu/legal-content/EN/TXT/?uri=CELEX:31994L0036. Accessed 26 April 2020.

13. Fadeel B, Garcia-Bennett AE. Better safe than sorry: Understanding the toxicological properties of inorganic nanoparticles manufactured for biomedical applications. Adv Drug Deliv Rev. 2010;62(3):362-74.

14. Falck GCM, Lindberg HK, Suhonen S, Vippola M, Vanhala E, Catalán J, Savolainen K, Norppa H. Genotoxic effects of nanosized and fine TiO2. Hum Exp Toxicol. 2009;28:339-52.

15. Fukai T, Ushio-Fukai M. Superoxide dismutases: role in redox signaling, vascular function, and diseases. Antioxid Redox Signal. 2011;15(6):1583-606.

16. Carbon Black, Titanium Dioxide, and Talc. IARC Monographs on the Evaluation of Carcinogenic Risks to Humans. 2006. https://publications.iarc.fr/BookAnd-Report-Series/larc-Monographs-On-The-Identification-Of-Carcinogenic-Hazards-To-Humans/Carbon-Black-Titanium-Dioxide-And-Talc-2010.

17. Kang SJ, Kim BM, Lee YJ, Chung HW. Titanium dioxide nanoparticles trigger p53-mediated damage response in peripheral blood lymphocytes. Environ Mol Mutagen. 2008;49:399-405.

18. Kashanian F, Habibi-Rezaei M, Bagherpour AR, Seyedarabi A, Moosavi-Movahedi AA. Magnetic nanoparticles as double-edged swords: concentrationdependent ordering or disordering effects on lysozyme. RSC Advances. 2017;7:54813-22.

19. Lebeaupin C, Proics E, de Bieville CH, Rousseau D, Bonnafous S, Patouraux S, Adam G, Lavallard VJ, Rovere C, Le Thuc O, Saint-Paul MC, Anty R, Schneck AS, lannelli A, Gugenheim J, Tran A, Gual P, Bailly-Maitre B. ER stress induces NLRP3 inflammasome activation and hepatocyte death. Cell Death Dis. 2015;6(9):e1879.

20. Lomer MCE, Thompson RPH, Powell JJ. Fine and ultrafine particles of the diet: influence on the mucosal immune response and association with Crohn's disease. Proc Nutr Soc. 2002;61(1):123-30.

21. Lin Y, Jiang M, Chen W, Zhao T, Wei Y. Cancer and ER stress: Mutual crosstalk between autophagy, oxidative stress and inflammatory response. Biomed Pharmacother. 2019;118:109249.

22. Liu X, Chen J, Zhang J. AdipoR1-mediated miR-3908 inhibits glioblastoma tumorigenicity through downregulation of STAT2 associated with the AMPK/SIRT1 pathway. Oncol Rep. 2017;37(6):3387-96.

23. Marques MR, Loebenberg R, Almukainzi. Simulated biological fluids with possible application in dissolution testing. Dissolution Technol. 2011;18(3):1528.

24. Mozzini C, Cominacini L, Garbin U, Fratta Pasini AM. Endoplasmic Reticulum Stress, NRF2 Signalling and Cardiovascular Diseases in a Nutshell. Curr Atheroscler Rep. 2017;19(8):33.

25. Müller-Taubenberger A, Lupas AN, Li H, Ecke M, Simmeth E, Gerisch G. Calreticulin and calnexin in the endoplasmic reticulum are important for phagocytosis. EMBO J. 2001;20(23):6772-82.

26. Mumbauer S, Pascual J, Kolotuev I, Hamaratoglu F. Ferritin heavy chain protects the developing wing from reactive oxygen species and ferroptosis. PLoS Genet. 2019;15(9):e1008396.

27. Test No. 408: Repeated Dose 90-Day Oral Toxicity Study in Rodents. In: OECD Guidelines for the Testing of Chemicals, Section 4. OECD Publishing. 2018. https://doi.org/10.1787/9789264070707-en. Accessed 25 April 2020.

28. Patni S, Bhatia AL. Nanotechnology: A double edged sword. Asian J Exp Sci. 2008;22(2);153-66.

29. Park EJ, Yoon J, Choi K, Yi J, Park K. 2009. Induction of chronic inflammation in mice treated with titanium dioxide nanoparticles by intratracheal instillation. Toxicology 16;260(1-3):37-46.

30. Pias EK, Ekshyyan OY, Rhoads CA, Fuseler J, Harrison L, Aw TY. Differential effects of superoxide dismutase isoform expression on hydroperoxideinduced apoptosis in PC-12 cells. J Biol Chem. 2003;278(15):13294-301.

31. Proquin H, Rodríguez-Ibarra C, Moonen CG, Urrutia Ortega IM, Briedé JJ, de Kok TM, van Loveren H, Chirino YI. Titanium dioxide food additive (E171) induces ROS formation and genotoxicity: contribution of micro and nano-sized fractions. Mutagenesis. 2017;32(1):139-49.

32. Salminen A, Kaarniranta K, Kauppinen A. ER stress activates immunosuppressive network: implications for aging and Alzheimer's disease. J Mol Med (Berl). 2020;98(5):633-50.

33. Schembre SM, Cheng I, Wilkens LR, Albright CL, Marchand le L. Variations in bitter-taste receptor genes, dietary intake, and colorectal adenoma risk. Nutr Cancer. 2013;65(7):982-90. 
34. Solaiman SM, Algie J, Bakand S, Sluyter R, Sencadas V, Lerch M, Huang XF, Konstantinov K, Barker PJ. Nano-sunscreens - a double-edged sword in protecting consumers from harm: viewing Australian regulatory policies through the lenses of the European Union. Crit Rev Toxicol. 2019;49(2):122-39.

35. Tassinari R, Cubadda F, Moracci G, Aureli F, D'Amato, Valeri M, De Berardis B, Raggi A, Mantovani A, Passeri D, Rossi M, Maranghi F. Oral, short-term exposure to titanium dioxide nanoparticles in Sprague-Dawley rat: focus on reproductive and endocrine systems and spleen. Nanotoxicology. 2014;8(6):654-62.

36. S. FDA. Summary of Color Additives for Use in the United States in Foods, Drugs, Cosmetics, and Medical Devices. https://www.fda.gov/industry/coloradditive-inventories/summary-color-additives-use-united-states-foods-drugs-cosmetics-and-medical-devices. Accessed 26 April 2020.

37. Warheit DB, Brown SC, Donner EM. Acute and Subchronic Oral Toxicity Studies in Rats With Nanoscale and Pigment Grade Titanium Dioxide Particles. Food Chem Toxicol. 2015;84:208-24.

38. Walton PA, Pizzitelli M. Effects of peroxisomal catalase inhibition on mitochondrial function. Front Physiol. 2012;3:108.

39. Weir A, Westorhoff P, Fabricius L, Hristovski K, von Goetz N. Titanium dioxide nanoparticles in food and personal care products. Environ Sci Technol. 2012. 21;46(4):2242-50.

\section{Tables}

Table 1.

\begin{tabular}{lllllllll} 
Day & Male & \multicolumn{5}{c}{ Female } \\
\cline { 2 - 8 } & Control & $10 \mathrm{mg} / \mathrm{kg} / \mathrm{day}$ & $100 \mathrm{mg} / \mathrm{kg} / \mathrm{day}$ & $1000 \mathrm{mg} / \mathrm{kg} / \mathrm{day}$ & Control & $10 \mathrm{mg} / \mathrm{kg} / \mathrm{day}$ & $100 \mathrm{mg} / \mathrm{kg} / \mathrm{day}$ & $1000 \mathrm{mg} / \mathrm{kg} / \mathrm{day}$ \\
\hline 5 & $30.7 \pm 1.88$ & $32.1 \pm 1.11$ & $30.0 \pm 1.15$ & $31.4 \pm 1.32$ & $22.8 \pm 1.11$ & $23.6 \pm 2.08$ & $22.8 \pm 1.45$ & $22.0 \pm 0.82$ \\
\hline 11 & $33.3 \pm 1.23$ & $35.8 \pm 0.89+$ & $33.5 \pm 1.76$ & $35.7 \pm 1.89+$ & $24.0 \pm 1.45$ & $23.9 \pm 2.17$ & $24.1 \pm 1.28$ & $23.2 \pm 0.75$ \\
\hline 18 & $35.9 \pm 1.42$ & $37.8 \pm 1.94 *$ & $36.2 \pm 2.05$ & $39.1 \pm 1.55+$ & $26.5 \pm 1.27$ & $26.9 \pm 2.35$ & $26.5 \pm 2.19$ & $25.1 \pm 1.28$ \\
\hline 25 & $36.4 \pm 1.25$ & $37.9 \pm 2.18$ & $36.5 \pm 2.08$ & $40.0 \pm 2.8+$ & $26.7 \pm 1.53$ & $26.6 \pm 2.40$ & $26.6 \pm 2.42$ & $25.7 \pm 1.12$ \\
\hline 32 & $36.4 \pm 0.79$ & $36.9 \pm 1.81$ & $36.7 \pm 2.21$ & $39.5 \pm 2.76+$ & $27.2 \pm 1.81$ & $27.1 \pm 2.34$ & $27.2 \pm 3.81$ & $26.2 \pm 1.55$ \\
\hline 39 & $36.6 \pm 1.04$ & $38.1 \pm 2.6$ & $37.7 \pm 2.19$ & $38.7 \pm 3.97$ & $27.6 \pm 2.20$ & $27.1 \pm 2.17$ & $26.5 \pm 2.75$ & $25.7 \pm 1.86$ \\
\hline 46 & $36.8 \pm 0.85$ & $38.4 \pm 2.47$ & $37.7 \pm 1.90$ & $40.4 \pm 3.04+$ & $27.7 \pm 1.63$ & $28.3 \pm 2.75$ & $27.3 \pm 2.88$ & $26.4 \pm 1.49$ \\
\hline 53 & $36.5 \pm 1.74$ & $37.7 \pm 2.28$ & $37.4 \pm 2.73$ & $40.1 \pm 3.07+$ & $27.8 \pm 2.19$ & $27.6 \pm 2.63$ & $27.2 \pm 2.58$ & $26.3 \pm 1.16$ \\
\hline 60 & $35.8 \pm 1.26$ & $37.5 \pm 2.32$ & $36.9 \pm 1.94$ & $38.4 \pm 2.42+$ & $26.5 \pm 2.17$ & $26.0 \pm 1.91$ & $26.0 \pm 1.82$ & $24.7 \pm 1.88$ \\
\hline 67 & $35.8 \pm 0.81$ & $37.9 \pm 2.28$ & $37.1 \pm 2.33$ & $38.0 \pm 2.91 *$ & $27.0 \pm 2.74$ & $26.2 \pm 1.81$ & $26.0 \pm 1.99$ & $24.8 \pm 1.27$ \\
\hline 74 & $36.1 \pm 0.90$ & $37.6 \pm 2.43$ & $37.1 \pm 1.85$ & $38.1 \pm 2.25$ & $26.6 \pm 1.80$ & $26.1 \pm 1.77$ & $25.5 \pm 1.91$ & $24.9 \pm 1.60$ \\
\hline 81 & $36.2 \pm 1.10$ & $37.3 \pm 2.18$ & $36.7 \pm 1.88$ & $38.6 \pm 2.33+$ & $25.6 \pm 2.24$ & $24.7 \pm 1.44$ & $24.2 \pm 1.66$ & $24.9 \pm 1.19$ \\
\hline 88 & $35.1 \pm 0.89$ & $37.7 \pm 1.82+$ & $36.2 \pm 2.30$ & $38.5 \pm 2.16+$ & $25.4 \pm 1.58$ & $23.7 \pm 1.77$ & $24.3 \pm 1.82$ & $24.1 \pm 1.47$
\end{tabular}

* Significant differences from control group $(p<0.05)$.

+ Significant differences from control group $(p<0.01)$.

Table 2. 


\begin{tabular}{|c|c|c|c|c|c|c|c|c|c|}
\hline & Unit & Male & & & & Female & & & \\
\hline & & Control & $\begin{array}{l}10 \\
\mathrm{mg} / \mathrm{kg} / \text { day }\end{array}$ & $\begin{array}{l}100 \\
\mathrm{mg} / \mathrm{kg} / \text { day }\end{array}$ & $\begin{array}{l}1000 \\
\mathrm{mg} / \mathrm{kg} / \text { day }\end{array}$ & Control & $10 \mathrm{mg} / \mathrm{kg} / \mathrm{day}$ & $\begin{array}{l}100 \\
\mathrm{mg} / \mathrm{kg} / \text { day }\end{array}$ & $\begin{array}{l}1000 \\
\mathrm{mg} / \mathrm{kg} / \mathrm{d}\end{array}$ \\
\hline $\mathrm{RBC}$ & $\begin{array}{l}\left(x 10^{\wedge} 6 /\right. \\
\mu L)\end{array}$ & $8.8 \pm 0.34$ & $8.8 \pm 0.50$ & $8.7 \pm 0.41$ & $8.8 \pm 0.35$ & $8.1 \pm 0.28$ & $8.0 \pm 0.25$ & $8.0 \pm 0.47$ & $8.1 \pm 0.40$ \\
\hline HGB & $(\mathrm{g} / \mathrm{dL})$ & $15.3 \pm 0.52$ & $15.5 \pm 0.73$ & $15.6 \pm 0.62$ & $15.5 \pm 0.49$ & $15.3 \pm 0.71$ & $15.4 \pm 0.42$ & $15.2 \pm 0.82$ & $15.3 \pm 0.6 i$ \\
\hline HCT & $(\%)$ & $48.9 \pm 1.60$ & $49.6 \pm 2.40$ & $49.7 \pm 1.66$ & $49.3 \pm 1.57$ & $47.6 \pm 2.10$ & $47.3 \pm 1.12$ & $46.7 \pm 2.49$ & $47.0 \pm 1.6 c$ \\
\hline MCV & $(\mathrm{fL})$ & $55.5 \pm 1.09$ & $56.4 \pm 1.59$ & $57.1 \pm 1.72$ & $56.2 \pm 1.30$ & $59.0 \pm 1.94$ & $59.0 \pm 0.80$ & $58.1 \pm 1.36$ & $57.8 \pm 1.7$ ? \\
\hline $\mathrm{MCH}$ & (pg) & $17.3 \pm 0.40$ & $17.7 \pm 0.78$ & $18.0 \pm 0.68$ & $17.6 \pm 0.58$ & $18.9 \pm 0.65$ & $19.2 \pm 0.21$ & $19.0 \pm 0.52$ & $18.9 \pm 0.7$ \\
\hline $\mathrm{MCHC}$ & $(\mathrm{g} / \mathrm{dL})$ & $31.2 \pm 0.37$ & $31.2 \pm 0.60$ & $31.5 \pm 0.32$ & $31.4 \pm 0.36$ & $32.1 \pm 0.70$ & $32.6 \pm 0.32$ & $32.7 \pm 0.41$ & $32.6 \pm 0.7 !$ \\
\hline RET & $(\%)$ & $2.0 \pm 0.18$ & $2.0 \pm 0.26$ & $2.1 \pm 0.34$ & $2.1 \pm 0.23$ & $2.1 \pm 0.43$ & $2.0 \pm 0.29$ & $1.9 \pm 0.29$ & $1.8 \pm 0.25$ \\
\hline RETA & $\left(10^{\wedge} 9 / \mathrm{L}\right)$ & $174.0 \pm 19.30$ & $179.1 \pm 23.54$ & $185.3 \pm 27.26$ & $181.8 \pm 19.75$ & $173.2 \pm 35.13$ & $157.0 \pm 22.11$ & $149.6 \pm 18.42$ & $148.6 \pm 21$ \\
\hline PLT & $\left(10^{3} / \mu \mathrm{L}\right)$ & $1021.4 \pm 132.04$ & $983.0 \pm 165.33$ & $900.2 \pm 211.36$ & $964.1 \pm 130.45$ & $984.1 \pm 104.94$ & $1023.2 \pm 100.38$ & $1055.2 \pm 118.41$ & $872.4 \pm 17$ \\
\hline NEU & $(\%)$ & $12.9 \pm 4.34$ & $18.7 \pm 6.34$ & $15.3 \pm 4.57$ & $18.7 \pm 6.64$ & $15.0 \pm 5.11$ & $14.0 \pm 4.67$ & $13.2 \pm 4.84$ & $15.8 \pm 3.36$ \\
\hline LYM & $(\%)$ & $82.0 \pm 4.71$ & $75.2 \pm 5.89 *$ & $79.3 \pm 4.75$ & $75.2 \pm 6.39 *$ & $78.7 \pm 4.85$ & $79.8 \pm 4.92$ & $81.0 \pm 4.84$ & $78.9 \pm 3.6$ \\
\hline EOS & $(\%)$ & $1.4 \pm 0.45$ & $1.5 \pm 0.60$ & $1.3 \pm 0.41$ & $1.4 \pm 0.27$ & $1.6 \pm 0.78$ & $1.7 \pm 0.50$ & $1.4 \pm 0.34$ & $1.2 \pm 0.43$ \\
\hline MON & $(\%)$ & $2.7 \pm 0.92$ & $3.5 \pm 1.13$ & $3.1 \pm 0.82$ & $3.4 \pm 0.49$ & $3.6 \pm 1.41$ & $3.4 \pm 0.81$ & $2.9 \pm 0.98$ & $2.7 \pm 0.72$ \\
\hline BAS & $(\%)$ & $0.3 \pm 0.07$ & $0.4 \pm 0.14$ & $0.4 \pm 0.10$ & $0.3 \pm 0.11$ & $0.4 \pm 0.16$ & $0.4 \pm 0.21$ & $0.5 \pm 0.25$ & $0.5 \pm 0.19$ \\
\hline LUC & $(\%)$ & $0.7 \pm 0.57$ & $0.7 \pm 0.36$ & $0.7 \pm 0.23$ & $0.9 \pm 0.74$ & $0.8 \pm 0.42$ & $0.8 \pm 0.21$ & $0.9 \pm 0.46$ & $0.9 \pm 0.34$ \\
\hline WBC & $\begin{array}{l}\left(x 10^{3} /\right. \\
\mu \mathrm{L})\end{array}$ & $10.2 \pm 1.58$ & $11.6 \pm 3.13$ & $11.2 \pm 2.40$ & $9.9 \pm 2.63$ & $8.4 \pm 1.81$ & $7.7 \pm 1.80$ & $6.7 \pm 1.47$ & $7.0 \pm 1.05$ \\
\hline
\end{tabular}

* Significant differences from control group $(p<0.05)$.

Table 3. 


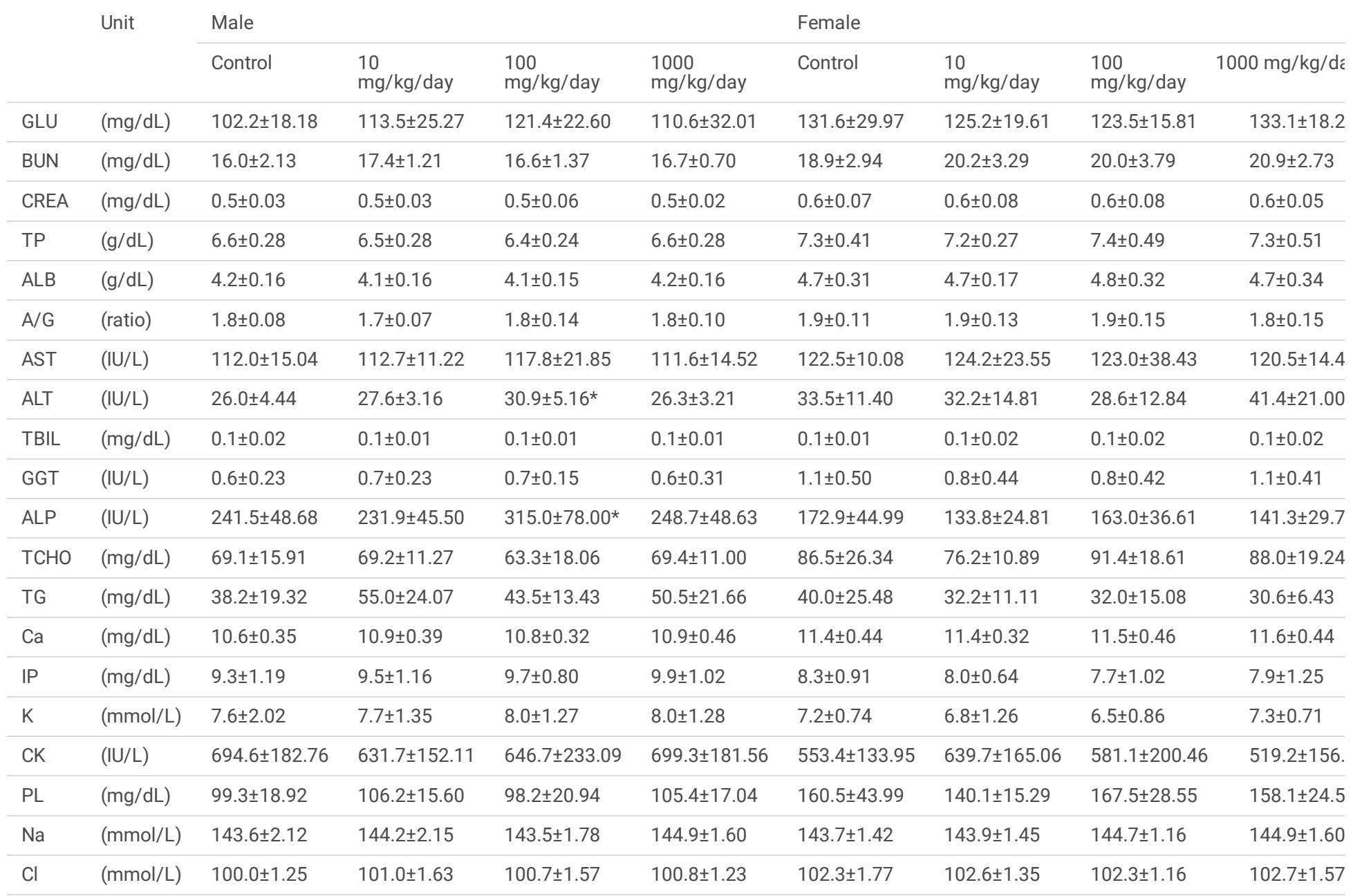

* Significant differences from control group $(p<0.05)$.

Table 4. 


\begin{tabular}{|c|c|c|c|c|c|c|c|c|}
\hline \multirow[t]{2}{*}{ Unit (g) } & \multicolumn{4}{|l|}{ Male } & \multicolumn{4}{|l|}{ Female } \\
\hline & Control & $10 \mathrm{mg} / \mathrm{kg} / \mathrm{day}$ & $\begin{array}{l}100 \\
\mathrm{mg} / \mathrm{kg} / \text { day }\end{array}$ & $\begin{array}{l}1000 \\
\mathrm{mg} / \mathrm{kg} / \text { day }\end{array}$ & Control & $\begin{array}{l}10 \\
\mathrm{mg} / \mathrm{kg} / \text { day }\end{array}$ & $\begin{array}{l}100 \\
\mathrm{mg} / \mathrm{kg} / \text { day }\end{array}$ & $1000 \mathrm{mg} / \mathrm{kg} / \mathrm{da}$ \\
\hline $\begin{array}{l}\text { Adrenal } \\
\text { glands }\end{array}$ & $0.066 \pm 0.0071$ & $0.071 \pm 0.0044$ & $0.064 \pm 0.0061$ & $0.061 \pm 0.0085$ & $0.079 \pm 0.0070$ & $0.076 \pm 0.0108$ & $0.079 \pm 0.0128$ & $0.080 \pm 0.01$ \\
\hline Brain & $2.234 \pm 0.1488$ & $2.249 \pm 0.0753$ & $2.205 \pm 0.0561$ & $2.325 \pm 0.0952$ & $2.052 \pm 0.1048$ & $2.045 \pm 0.0894$ & $2.025 \pm 0.0653$ & $2.029 \pm 0.08$ \\
\hline Heart & $1.705 \pm 0.1833$ & $1.761 \pm 0.1180$ & $1.726 \pm 0.1538$ & $1.819 \pm 0.0881$ & $1.089 \pm 0.1107$ & $1.110 \pm 0.0644$ & $1.081 \pm 0.1289$ & $1.035 \pm 0.07$ \\
\hline Kidneys & $4.174 \pm 0.5196$ & $4.288 \pm 0.5575$ & $3.870 \pm 0.4626$ & $4.241 \pm 0.3319$ & $2.384 \pm 0.2765$ & $2.241 \pm 0.2814$ & $2.272 \pm 0.3628$ & $2.331 \pm 0.24 \varepsilon$ \\
\hline Liver & $16.675 \pm 2.1430$ & $17.514 \pm 2.4145$ & $16.330 \pm 2.4597$ & $18.297 \pm 2.8235$ & $9.194 \pm 1.0113$ & $8.936 \pm 1.0157$ & $9.197 \pm 1.3309$ & $8.708 \pm 0.58$ \\
\hline Spleen & $0.923 \pm 0.1256$ & $0.970 \pm 0.1492$ & $0.964 \pm 0.1673$ & $0.997 \pm 0.1510$ & $0.623 \pm 0.0779$ & $0.651 \pm 0.1442$ & $0.584 \pm 0.0800$ & $0.572 \pm 0.09$ \\
\hline Thymus & $0.433 \pm 0.0761$ & $0.427 \pm 0.0568$ & $0.454 \pm 0.1055$ & $0.426 \pm 0.0701$ & $0.402 \pm 0.0732$ & $0.370 \pm 0.0486$ & $0.319 \pm 0.1072$ & $0.332 \pm 0.05$ \\
\hline $\begin{array}{l}\text { Thyroid and } \\
\text { parathyroid } \\
\text { glands }\end{array}$ & $0.025 \pm 0.0059$ & $0.032 \pm 0.0068$ & $0.028 \pm 0.0050$ & $0.029 \pm 0.0057$ & $0.021 \pm 0.0039$ & $0.023 \pm 0.0045$ & $0.021 \pm 0.0027$ & $0.025 \pm 0.00$ \\
\hline Lung & $1.835 \pm 0.2212$ & $1.891 \pm 0.1013$ & $1.892 \pm 0.2010$ & $1.905 \pm 0.1292$ & $1.335 \pm 0.1777$ & $1.367 \pm 0.0911$ & $1.363 \pm 0.1483$ & $1.325 \pm 0.09$ \\
\hline Testes & $3.690 \pm 0.3563$ & $3.851 \pm 0.1839$ & $3.532 \pm 0.4235$ & $3.735 \pm 0.4352$ & - & - & - & - \\
\hline Ovaries & - & - & - & - & $0.107 \pm 0.0198$ & $0.095 \pm 0.0091$ & $0.093 \pm 0.0212$ & $0.094 \pm 0.01$ \\
\hline Uterus/cervix & - & - & - & - & $0.699 \pm 0.1673$ & $0.884 \pm 0.3095$ & $0.732 \pm 0.1485$ & $0.668 \pm 0.18$ \\
\hline
\end{tabular}

Table 5.

\begin{tabular}{|c|c|c|c|c|c|c|c|c|}
\hline \multirow[t]{2}{*}{ Unit (\%Body) } & \multicolumn{4}{|l|}{ Male } & \multicolumn{4}{|l|}{ Female } \\
\hline & Control & $\begin{array}{l}10 \\
\mathrm{mg} / \mathrm{kg} / \text { day }\end{array}$ & $\begin{array}{l}100 \\
\mathrm{mg} / \mathrm{kg} / \text { day }\end{array}$ & $\begin{array}{l}1000 \\
\mathrm{mg} / \mathrm{kg} / \text { day }\end{array}$ & Control & $\begin{array}{l}10 \\
\mathrm{mg} / \mathrm{kg} / \text { day }\end{array}$ & $\begin{array}{l}100 \\
\mathrm{mg} / \mathrm{kg} / \text { day }\end{array}$ & 1000 mg/kg/day \\
\hline $\begin{array}{l}\text { Adrenal } \\
\text { glands }\end{array}$ & $0.011 \pm 0.0017$ & $0.012 \pm 0.0012$ & $0.011 \pm 0.0009$ & $0.010 \pm 0.0014^{*}$ & $0.023 \pm 0.0031$ & $0.023 \pm 0.0033$ & $0.024 \pm 0.0025$ & $0.025 \pm 0.0036$ \\
\hline Brain & $0.384 \pm 0.0342$ & $0.379 \pm 0.0306$ & $0.379 \pm 0.0380$ & $0.371 \pm 0.0345$ & $0.605 \pm 0.0415$ & $0.619 \pm 0.0496$ & $0.639 \pm 0.0642$ & $0.637 \pm 0.0369$ \\
\hline Heart & $0.292 \pm 0.0158$ & $0.296 \pm 0.0201$ & $0.295 \pm 0.0156$ & $0.289 \pm 0.0159$ & $0.320 \pm 0.0182$ & $0.335 \pm 0.0237$ & $0.338 \pm 0.0119$ & $0.325 \pm 0.0178$ \\
\hline Kidneys & $0.714 \pm 0.0618$ & $0.717 \pm 0.0524$ & $0.660 \pm 0.0536$ & $0.674 \pm 0.0432$ & $0.700 \pm 0.0648$ & $0.678 \pm 0.0950$ & $0.713 \pm 0.1072$ & $0.730 \pm 0.0579$ \\
\hline Liver & $2.846 \pm 0.1569$ & $2.926 \pm 0.1890$ & $2.774 \pm 0.2335$ & $2.886 \pm 0.2117$ & $2.697 \pm 0.1798$ & $2.690 \pm 0.2217$ & $2.877 \pm 0.2500$ & $2.730 \pm 0.0917$ \\
\hline Spleen & $0.158 \pm 0.0210$ & $0.163 \pm 0.0228$ & $0.164 \pm 0.0187$ & $0.158 \pm 0.0217$ & $0.183 \pm 0.0212$ & $0.197 \pm 0.0447$ & $0.182 \pm 0.0161$ & $0.179 \pm 0.0286$ \\
\hline Thymus & $0.075 \pm 0.0144$ & $0.072 \pm 0.0119$ & $0.077 \pm 0.0164$ & $0.068 \pm 0.0125$ & $0.119 \pm 0.0242$ & $0.112 \pm 0.0164$ & $0.098 \pm 0.0236$ & $0.104 \pm 0.0152$ \\
\hline $\begin{array}{l}\text { Thyroid and } \\
\text { parathyroid } \\
\text { glands }\end{array}$ & $0.004 \pm 0.0013$ & $0.005 \pm 0.0014$ & $0.005 \pm 0.0007$ & $0.005 \pm 0.0010$ & $0.006 \pm 0.0009$ & $0.007 \pm 0.0011$ & $0.006 \pm 0.0005$ & $0.008 \pm 0.0019$ \\
\hline Lung & $0.314 \pm 0.0213$ & $0.319 \pm 0.0330$ & $0.324 \pm 0.0387$ & $0.303 \pm 0.0163$ & $0.392 \pm 0.0478$ & $0.413 \pm 0.0363$ & $0.427 \pm 0.0379$ & $0.416 \pm 0.0247$ \\
\hline Testes & $0.635 \pm 0.0819$ & $0.649 \pm 0.0590$ & $0.603 \pm 0.0595$ & $0.593 \pm 0.0638$ & - & - & - & - \\
\hline Ovaries & - & - & - & - & $0.032 \pm 0.0063$ & $0.029 \pm 0.0036$ & $0.029 \pm 0.0064$ & $0.030 \pm 0.0054$ \\
\hline Uterus/cervix & - & - & - & - & $0.207 \pm 0.0559$ & $0.269 \pm 0.1007$ & $0.230 \pm 0.0470$ & $0.209 \pm 0.0552$ \\
\hline
\end{tabular}

Table 7. 


\begin{tabular}{|c|c|c|c|c|c|c|c|}
\hline \multirow[t]{2}{*}{ Elements } & \multirow[t]{2}{*}{ Tissues } & \multicolumn{4}{|l|}{ Male } & \multicolumn{2}{|l|}{ Female } \\
\hline & & Control & $10 \mathrm{mg} / \mathrm{kg} /$ day & 100 mg/kg/day & 1000 mg/kg/day & Control & $10 \mathrm{mg} / \mathrm{kg} /$ day \\
\hline \multirow[t]{3}{*}{$\mathrm{Ti}$} & Colon & $23.77 \pm 11.12$ & $15.88 \pm 2.30$ & $15.09 \pm 5.43$ & $88.36 \pm 68.06$ & $13.94 \pm 1.07$ & $19.19 \pm 3.04$ \\
\hline & Kidney & $12.61 \pm 3.78$ & $9.06 \pm 1.77$ & $7.75 \pm 1.30$ & $10.46 \pm 1.76$ & $8.04 \pm 0.71$ & $4.59 \pm 4.39$ \\
\hline & Spleen & $7.96 \pm 1.18$ & $8.04 \pm 1.25$ & $8.66 \pm 1.45$ & $9.89 \pm 1.66$ & $14.90 \pm 2.27$ & $20.08 \pm 6.59$ \\
\hline \multirow[t]{3}{*}{$\mathrm{Cu}$} & Colon & $58.80 \pm 14.37$ & $47.34 \pm 3.64$ & $76.35 \pm 71.18$ & $50.36 \pm 16.16$ & $45.09 \pm 4.43$ & $55.29 \pm 7.54$ \\
\hline & Kidney & $278.11 \pm 103.50$ & $238.06 \pm 69.65$ & $217.14 \pm 32.48$ & $295.57 \pm 70.45$ & $222.71 \pm 70.10$ & $183.85 \pm 70.88$ \\
\hline & Spleen & $35.76 \pm 2.07$ & $36.53 \pm 2.38$ & $35.61 \pm 1.75$ & $40.73 \pm 1.89$ & $45.34 \pm 10.54$ & $57.15 \pm 19.99$ \\
\hline \multirow[t]{3}{*}{$\mathrm{Zn}$} & Colon & $760.24 \pm 144.80$ & $910.06 \pm 377.72$ & $696.52 \pm 96.71$ & $671.09 \pm 216.05$ & $596.62 \pm 39.06$ & $728.81 \pm 30.65$ \\
\hline & Kidney & $1011.85 \pm 282.96$ & $1057.20 \pm 302.94$ & $976.61 \pm 436.19$ & $914.13 \pm 343.48$ & $821.49 \pm 144.23$ & $652.90 \pm 117.79$ \\
\hline & Spleen & $632.37 \pm 122.70$ & $515.70 \pm 78.48$ & $537.50 \pm 87.79$ & $522.81 \pm 45.71$ & $654.56 \pm 219.42$ & $734.65 \pm 275.96$ \\
\hline \multirow[t]{3}{*}{$\mathrm{Mn}$} & Colon & $87.40 \pm 56.83$ & $59.85 \pm 15.08$ & $62.65 \pm 32.41$ & $98.20 \pm 77.90$ & $54.41 \pm 6.45$ & $70.36 \pm 49.15$ \\
\hline & Kidney & $22.52 \pm 3.83$ & $22.00 \pm 2.85$ & $21.96 \pm 3.52$ & $22.53 \pm 1.59$ & $21.38 \pm 4.15$ & $17.76 \pm 5.62$ \\
\hline & Spleen & $3.06 \pm 4.55$ & $0.00 \pm 0.00$ & $0.00 \pm 0.00$ & $5.23 \pm 11.69$ & $8.96 \pm 2.48$ & $8.37 \pm 5.56$ \\
\hline \multirow[t]{3}{*}{$\mathrm{Fe}$} & Colon & $557.43 \pm 249.13$ & $516.72 \pm 144.24$ & $487.96 \pm 169.00$ & $631.65 \pm 216.66$ & $552.75 \pm 96.13$ & $594.99 \pm 139.47$ \\
\hline & Kidney & $2637.77 \pm 786.48$ & $3076.00 \pm 278.06$ & $2532.63 \pm 301.48$ & $2671.22 \pm 369.98$ & $3409.95 \pm 931.98$ & $2738.79 \pm 1021$ \\
\hline & Spleen & $45652.03 \pm 14827.78$ & $40977.14 \pm 6214.30$ & $41224.01 \pm 12560.41$ & $37728.32 \pm 8055.82$ & $101149.21 \pm 15471.51$ & $102838.33 \pm 45$ \\
\hline \multirow[t]{3}{*}{$\mathrm{Al}$} & Colon & $366.51 \pm 87.04$ & $336.16 \pm 62.58$ & $316.55 \pm 87.90$ & $421.37 \pm 165.21$ & $264.36 \pm 53.29$ & $290.99 \pm 110.45$ \\
\hline & Kidney & $348.47 \pm 103.00$ & $363.93 \pm 123.26$ & $252.40 \pm 31.65$ & $297.47 \pm 44.71$ & $327.22 \pm 31.03$ & $336.02 \pm 86.53$ \\
\hline & Spleen & $353.85 \pm 45.61$ & $325.20 \pm 73.09$ & $382.98 \pm 79.61$ & $524.26 \pm 349.04$ & $291.33 \pm 61.33$ & $358.79 \pm 108.06$ \\
\hline
\end{tabular}

\section{Figures}



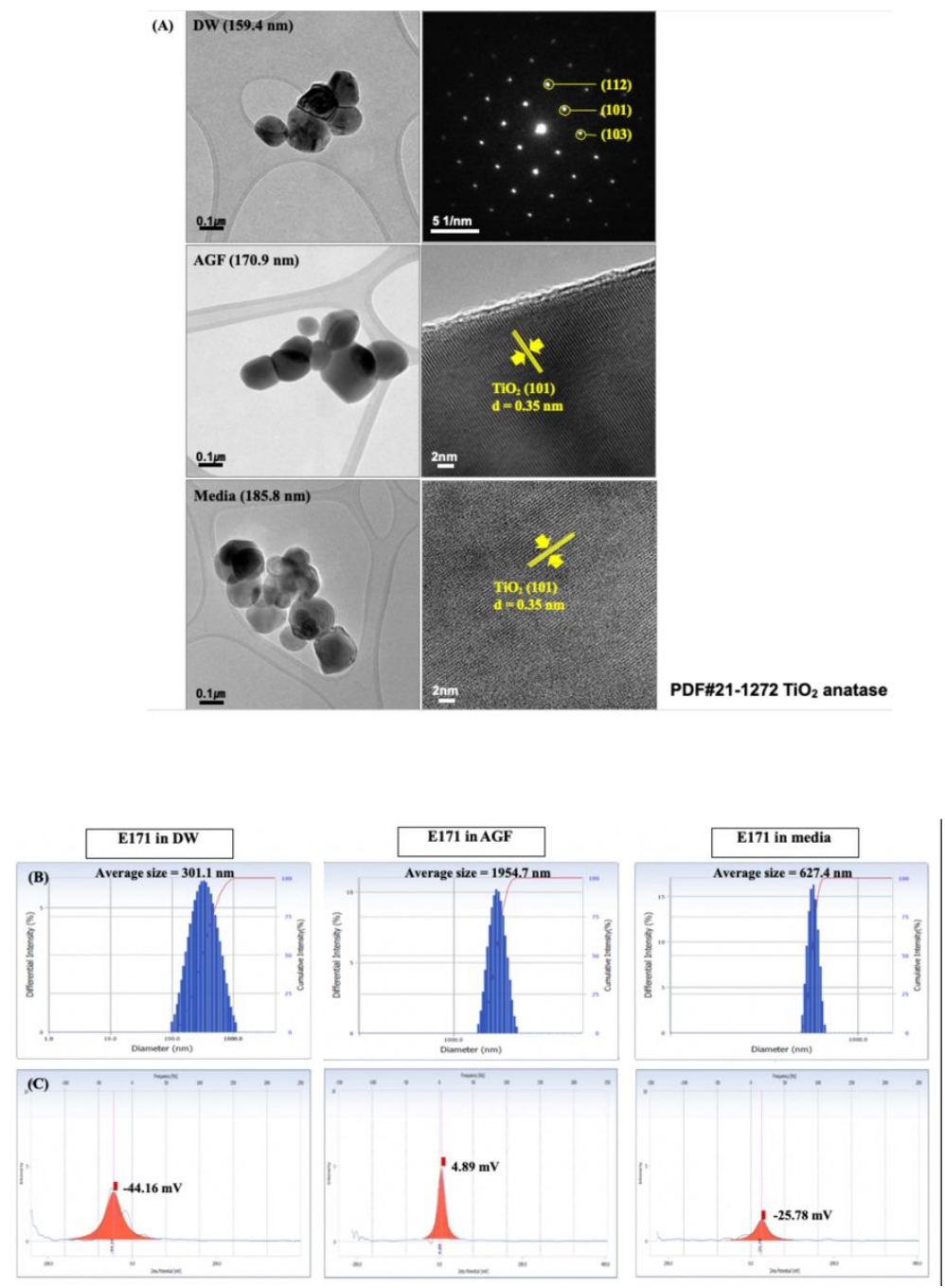

Figure 1

Characterization of E171. E171 was first suspended in DW and then diluted (1:1 of volume ratio) using AGF and cell culture media. (A) TEM images of morphologies and crystal structures, (B) Particle size distribution, and (C) Zeta potential.
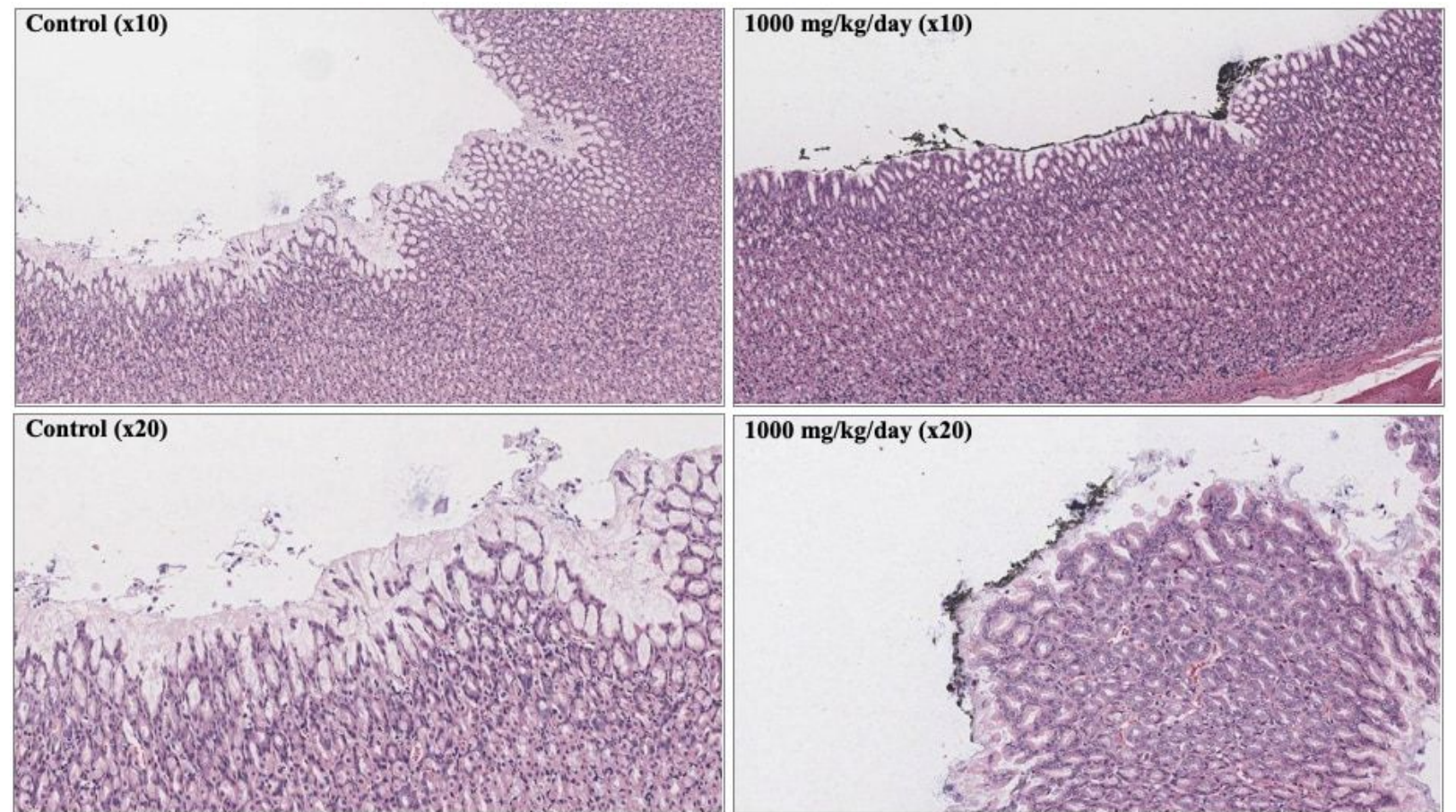

$1000 \mathrm{mg} / \mathrm{kg} / \mathrm{day}(\mathbf{x 2 0})$

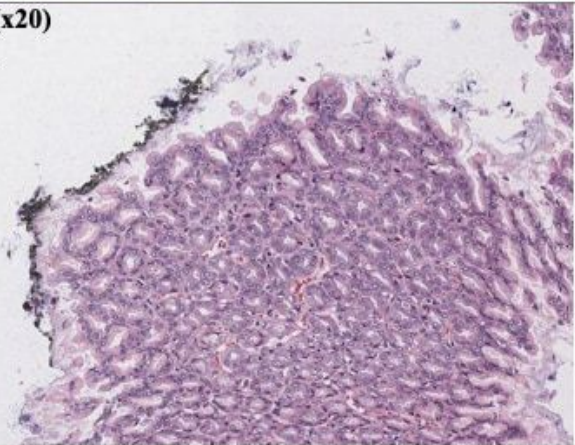


Figure 2

Microscopic findings in the stomach wall after treatment of E171. No remarkable findings were obtained from the $0 \mathrm{mg} / \mathrm{kg}$ dosed rat (control) whereas E171 accumulation was found at $1000 \mathrm{mg} / \mathrm{kg}$ dosed rat.

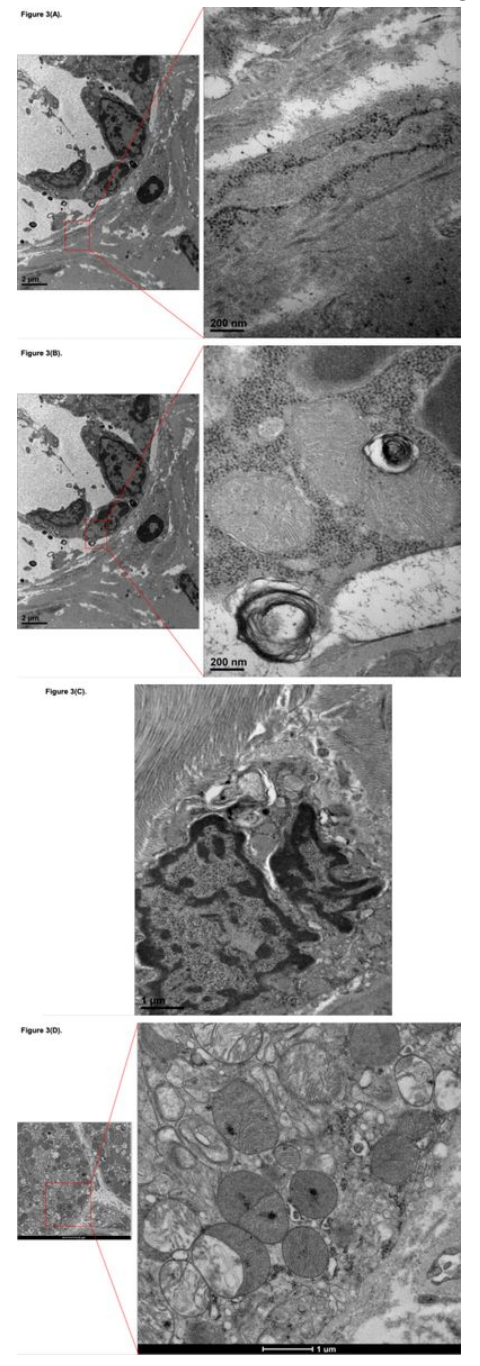

\section{Figure 3}

. TEM images of the colon tissue after treatment with $1,000 \mathrm{mg} / \mathrm{kg}$ of E171. Accumulation in cytosol (A, B) and the formation of lamellar body-like structure (B). E171 was also found in cytosol (C) and intracellular organelle such as mitochondria (D). 


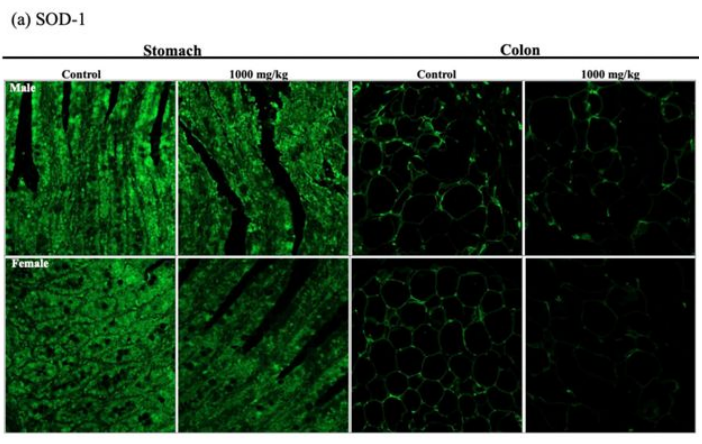

(b) SOD-2

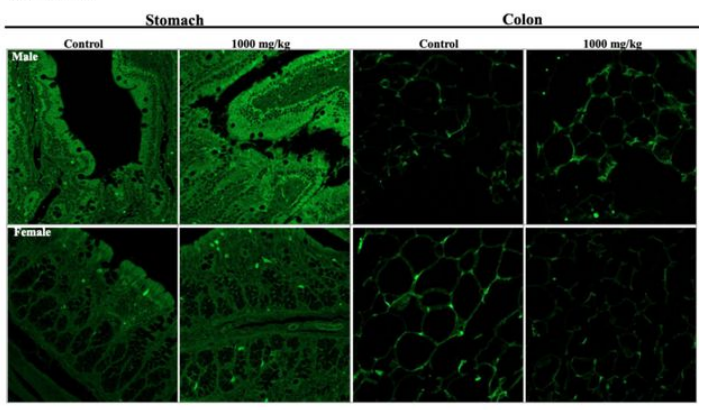

(c) Cytochrome $\mathrm{C}$

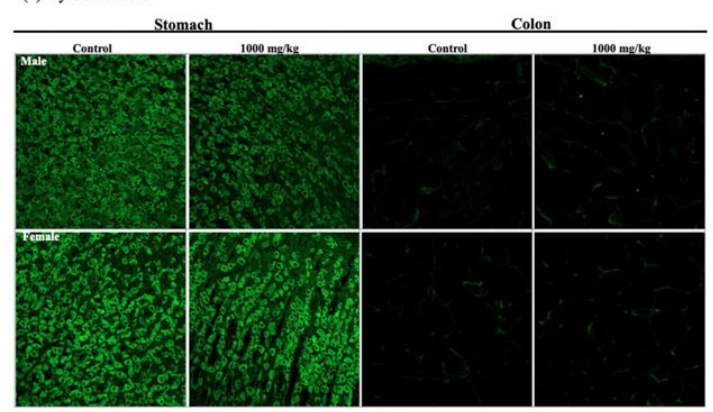

\section{Figure 4}

Immunofluorescence staining of stomach and colon tissue. Sections of control and highest dosing (1000 mg/kg) group were stained with (A) SOD-1, (B) SOD2 , and (C) cytochrome C. 

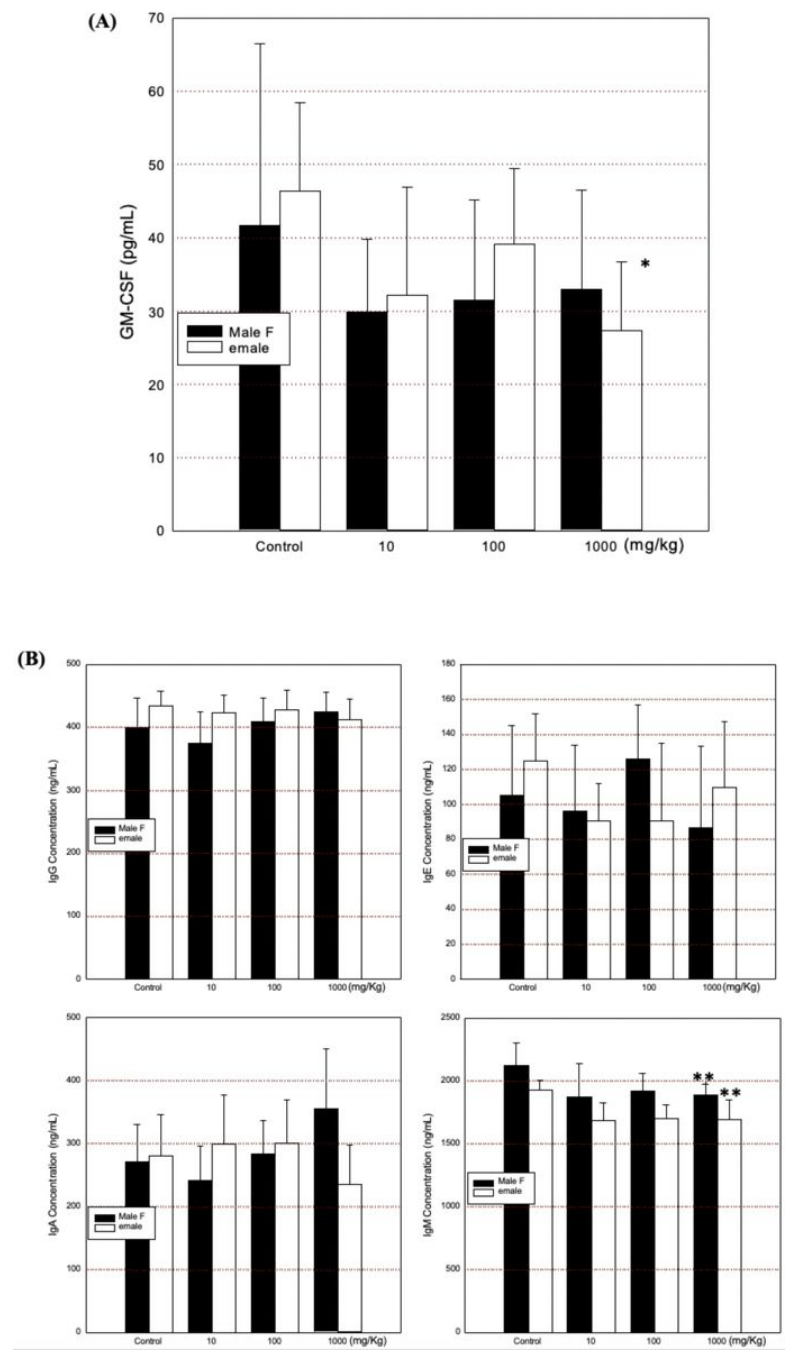

Figure 5

(A) Effects on secretion of GM-CSF and (B) immunoglobulin (IgG, $\lg A$, IgE, and $\lg M)$ in serum. All experiments were performed independently three times using two wells per sample and the results were represented as mean \pm SD.

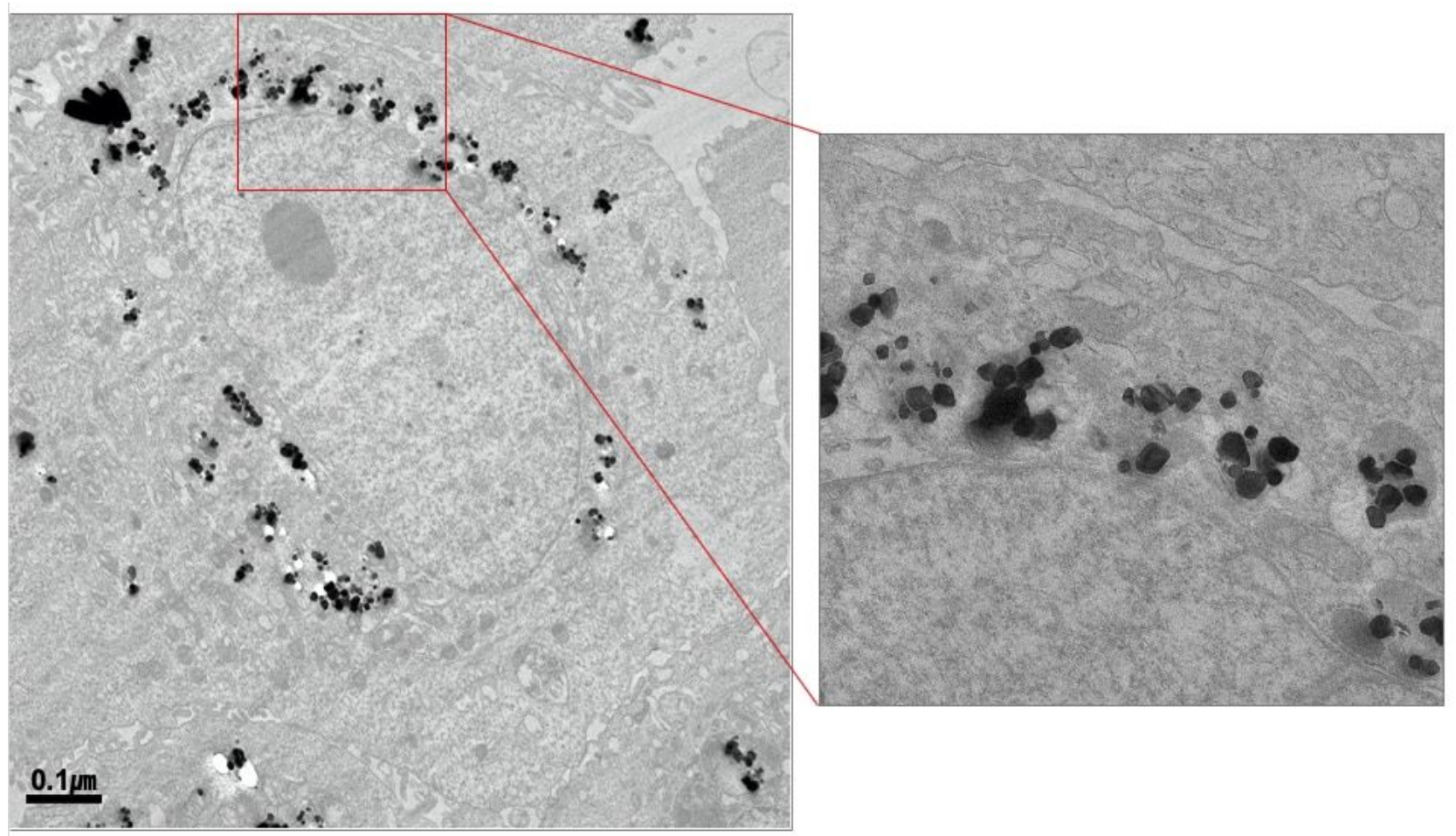


Figure 6

TEM images of AGS cells exposed to E171 $(40 \mu \mathrm{g} / \mathrm{mL})$ for $24 \mathrm{~h}$. The image show that E171 particles localize to the perinuclear region of the E171 treated cell.

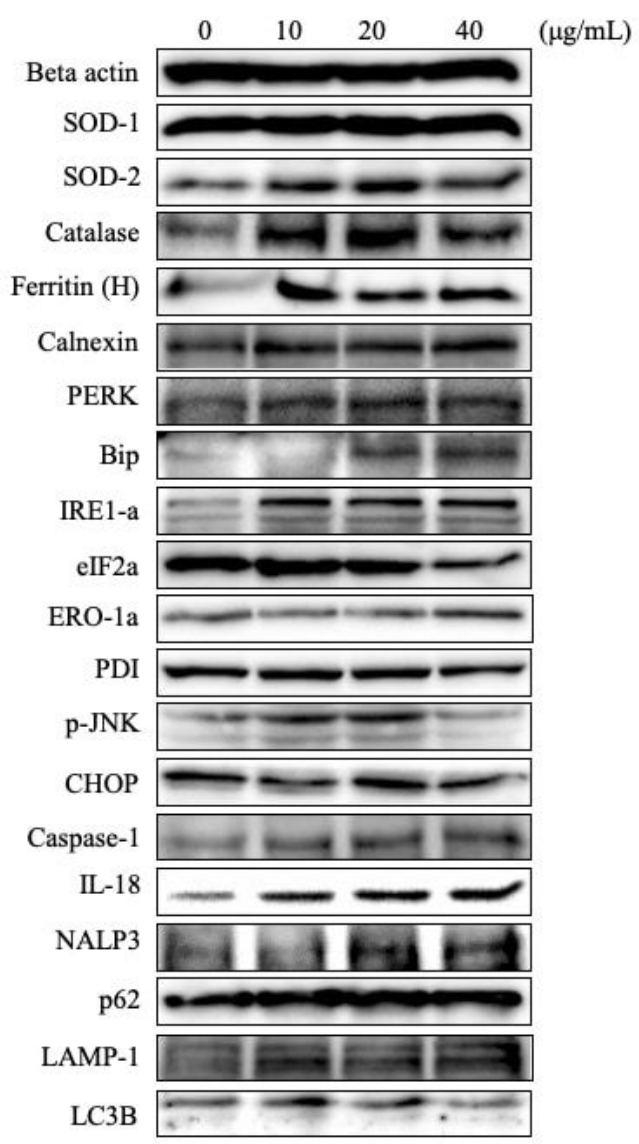

Figure 7

Changes in protein expression. AGS cells were harvested after $24 \mathrm{~h}$ of E171 treatment $(0,10,20$, and $40 \mu \mathrm{g} / \mathrm{mL})$ and blotted three times independently $(\mathrm{N}=3)$. All results showed similar trend and representative bands were presented.

\section{Supplementary Files}

This is a list of supplementary files associated with this preprint. Click to download.

- Si.pptx 